\title{
General distribution of different arthropods species associated with sunflower in Khyber Pakhtunkhwa: (A survey of Peshawar, Mardan and Swabi District:)
}

Fazal Said, Fazal Jalal ${ }^{*}$, Muhammad Imtiaz, Muhammad Ali Khan and Sayed Hussain

Department of Agriculture, Abdul Wali Khan University, Mardan-Pakistan

*Corresponding author's email: fazaljalal@awkum.edu.pk

Citation

Fazal Said, Fazal Jalal, Muhammad Imtiaz, Muhammad Ali Khan and Sayed Hussain. General distribution of different arthropods species associated with sunflower in Khyber Pakhtunkhwa: (A survey of Peshawar, Mardan and Swabi District:). Pure and Applied Biology Vol. 7, Issue 3, pp1144-1160. http://dx.doi.org/10.19045/bspab.2018.700134

Received: 31/04/2018 Revised: 09/07/2018 Accepted: 06/08/2018

Online First: 11/08/2018

\section{Abstract}

A field survey was carried out to record different insect pests, pollinators and natural enemies associated with sunflower, in three districts of Khyber Pakhtunkhwa i.e. Peshawar, Mardan and Swabi during 2012 and 2013. The collection was focused to recored insect pest, pollinators and natural enemies in spring and autum season on weekly basis from various sunflower fields till crop maturity. The districts were assigned as Site A (Peshawar), Site B (Mardan) and Site C (Swabi). Results showed that. Seedling and root feeding pests includedcutworm, Field crickets, Black field earwig and Grasshopper spp. Stem feeders insect included stem weevil and tree hoppers. Sucking pests were Whitefly, Leaf hoppers, Aphids and Green stink bug), defoliators included leaf beetle, Tobacco caterpillar, Cabbage semilooper and Hairy caterpillar and (Capitulum borer, Thrips, Brown stink bug and Seed Weevil recorded as capitulum or seed feeders. Apart from insect pests, honeybees, bumble bees, carpenter bees and halictid bees were recorded as pollinator associated with sunflower. Among the recorded insect pest, Lepidopterous insect were the most dominant (( milkweed butterfly, cabbage butterfly, yellow butterfly, diamondback moth and swallowtail butterflies) Followed by Dipterous insect that include, syrphid fly as pollinating agent of sunflower. Furthermore, ladybird beetle, green lacewing, praying mantis, syrphid flies, tachinid flies and certain species of spiders were the natural enemies associated insect complex of sunflower.

Keywords: Arthropods; Natural enemies; Pests; Pollinators Sunflower

Introduction

Edible oil is Pakistan's largest food commodity and it ranks 2 nd after petroleum.
In Pakistan, the edible out production is quite low, that fulfill only $23 \%$ of our domestic demand while the rest of edible oil is 
imported from different counties of the world... According Pakistan Oil Seed Development Board's (PODB), our country spent 224 billion Pakistani Rupees annually on the import of this single commodity. The considerable increase in country's population demands more edible oil that has to be substituted from local resources. Opportunities of indigenous oilseed productions have to be explored in the cropping system with future climate changes and increasing population of the country [1]. Sunflower (Helianthus annuиs L.) belongs to the family Compositae and it is generally cultivated in Pakistan as an oil producing crop [2]. According to [4] the area under cultivation of different oilseed crops in Pakistan is $3^{\prime} 704,940$ (ha) with the production of 3 ' 947,000 (tons), whereas area under cultivation of sunflower 155.30 thousand hectares with the production of 189.73 thousand tons annually.

Vulnerability of the sunflower insect pests and diseases is one of the main hurdles towards its production. Most of the insect pests attack on the buds and leaves, resulting in considerable yield reduction in sunflower production [5]. Moreover, some of these insect pests serve as vector for virus and other diseases. For instace, leaf curling, chlorosis and pre-mature senescence may be due to infestation of Empoasca abrupta g [6]. Cutworms (Agrotis spp.), American bollworm (Helicoverpa armigera Hubner), aphids (Aphis gossypii Glover), head caterpillar (Tathmopoda theoris Mayr), whitefly (Bemisia tabaci Gennadius) and several species of armyworms, grasshoppers, Loopers and jassids and beetles have been reported to be associated with sunflower [7-9] reported that whiteflies, aphids, thrips and leafhoppers are key sucking pests that contribute to yield loss of $46 \%$

Beside the insect pests, a wide range of pollinators and natural enemies also visit sunflower during the crop growth.
Honeybees (Apis mellifera L.) are the most important sunflower pollinators [10]. According to [11-12] honeybees may increase seed yield in sunflower by $30 \%$ and oil content of seed by $6 \%$ in hybrid varieties with self-fertility. Pollinating agents are indispensable; otherwise, without their services, the yield would be drastically reduced.

In addition to pollinators, natural enemies potentially suppress the incidence of insect pests; which may include green lacewing, reduvid bug, mantids, syrphid fly larvae, spotted beetle and different species of spiders. Of these, spotted beetles are of great importance since they are generalist that may feed on whitefly, aphids, thrips, mealybugs, and scales, Lepidoptera and Coleoptera [13-15]. For instance, syrphid fly larvae (Episyrphis balteatus DeGeer) feed on many small caterpillars, aphids, scales and mealybugs [16]. Also, ladybird beetles (Coccinella spp.) are voracious insect predators of aphids and significantly suppresses aphids' infestation on sunflower crops [17-18] these natural enemies keep the pest population below economic injury level which ultimately increase the productivity. Keeping in mind the economic importance of the sunflower crop in Pakistan, he current survey was therefore conducted to identify and document different arthropods species associated with sunflower in Peshawar, Mardan and Swabi districts in Khyber Pakhtunkhwa. The finding of this study may use as baseline for the taxonomist working on the arthropods fauna associated with sunflower at Peshawar valley of Khyber Pakthunkhwa.

\section{Materials and methods}

In the 2012-2013 growing season, in Peshawar (A), Mardan (B) and Swabi (C) districts, of Khyber Pakhtunkhwa, insect pests, pollinators and natural enemies were surveyed. The arthropods were collected on a weekly basis from the time of 
transplantation till crop harvesting

\section{Site A (Peshawar)}

Peshawar $\left(34.01^{\circ} \mathrm{N}, 71.53^{\circ} \mathrm{E}\right)$, is the capital of Khyber Pakhtunkhwa, with a total area of $1,257 \mathrm{~km}^{2}$. It is situated at an altitude of 347 $\mathrm{m}(1,138 \mathrm{ft})$ above sea level. The mean maximum temperature exceeds $40^{\circ}$ in summer while the mean minimum temperature is $25^{\circ} \mathrm{C}$. During winter, the mean minimum temperature is $4{ }^{\circ} \mathrm{C}$, whereas the maximum is $18.35{ }^{\circ} \mathrm{C}$. The average annual precipitation level recorded is 400 millimeters (16 in) and the highest annual rainfall level of 904.5 millimeters (35.61 in) during 2003. The relative humidity varies from 46 to $76 \%$ during June through August.

\section{Site B (Mardan)}

Mardan is situated at $34.20^{\circ} \mathrm{N}, 72.05^{\circ} \mathrm{E}$ with total area of $1,632 \mathrm{~km}^{2}$. Elevation of Mardan is 285 meters above the sea level. The temperature reaches its maximum in the month of June i.e. $41.5^{\circ} \mathrm{C}$. The mean minimum temperature recorded for the month of January is $2.1^{\circ} \mathrm{C}$. Maximum rainfall for August is $125.85 \mathrm{~mm}$. Maximum humidity has been recorded in December at $73.33 \%$. Due to the intensive cultivation and irrigation, the tract is generally moist and humid.

\section{Site C (Swabi)}

Swabi $\left(34.12^{\circ} \mathrm{N}, 72.47^{\circ} \mathrm{E}\right)$ is situated at 321 metersabove the sea level. Total area of Swabi is $1543 \mathrm{~km}^{2}$. Swabi is bounded by the district Buner in the north, in the east by Haripur district, on the south by district Attock, on the west by the Mardan and Nowshera Districts.

\section{Sampling procedure}

Methodologies adopted and materials used for collecting arthropods are briefed here.

\section{Collection}

Entomological nets were mainly used for collecting different arthropod species. Large and hard-bodied insects (grasshoppers and beetles) were picked by hand/ forceps and placed in the killing jar [19]. A sweep net was also used to collect flying insects including pollinators [20]. For collecting small insects, aspirator was used. The collected specimens were killed by placing them directly in the killing jar with Ethyl acetate and thus, the adult specimens were preserved directly, while the young ones were first reared to adult stage and after placing, those in killing jar were preserved.

\section{Collection of soil insects}

Soil insects like cut worm etc. were found under cracks, clods and plant residues near the base of damaged plants. For collecting cutworms, clods and soil around the newly damaged sunflower seedlings was carefully removed and collected specimens were dropped into a small jar with alcohol. Similarly, crickets and earwigs were directly collected by hands/ forceps and placed in the killing jar. Soil insects were generally inspected and collected soon after seedling emergence during initial growing stages of the crop.

\section{Preservation}

For preserving large and hard-bodied insects first, those were simply dip in boiling water for a more than one minute and then preserved in $70 \%$ alcohol. The small soft body specimens, were dip in hot water for about 30 second and then transfered themto 97\% alcohol for $24 \mathrm{hrs}$ before mounting on card point..

\section{Mounting}

Small size insects were kept in alcohol for 24 hours and then mounted on card points. The card was pinned through the base, and the small insects were glued to tip of the point. Each specimen was labeled with; (a) locality (b) collection date (c) collectors name and (d) host.All the collected specimens were kept in wooden collection box. To protect the specimens from museum pest attack and damp, naphthalene balls were placed in collection boxes. 


\section{Identification}

Identification and labeling of the specimens were carried out in the Entomology Museum at The University of Agriculture, Peshawar. Identification was done by using standard taxonomic literature; different available keys, and comparative pictures were used. Unidentified specimens were sent to taxonomist at National Insect Museum at Agriculture Research Centre (NARC), Islamabad. Finally, all the identified specimens were deposited in the insect museum of Department of Entomology, The University of Agriculture, Peshawar.

Results and discussion

\section{Insect pests associated with sunflower}

Among the insect pests associated with sunflower crop, some of them are just occasional and infrequent pests, whereas many insect pests cause severe damage in the initial growing stages of the crop. As the crop move towards maturity, many insect pests attack on buds and leaves of the plant, which leads to increased pest incidence. Table 1 indicates various insect pests that were recorded on sunflower crop. Sunflower pests were mainly divided into five major groups i.e. Seedling and root feeding pests, stem feeders, sucking pests, defoliators and capitulum or seed feeders.

Table 1. List of different insect pests recorded on sunflower in Peshawar, Mardan and Swabi districts of Khyber Pakhtunkhwa during 2012-2013

\begin{tabular}{|c|c|c|c|}
\hline S. No. & Group Names & Scientific Names & Order and Family \\
\hline 1 & $\begin{array}{l}\text { Seedling and Root } \\
\text { Feeding Pests } \\
\text { (i) Cutworm spp. } \\
\text { (ii) Black field crickets } \\
\text { (iii) Brown field crickets } \\
\text { (iv) Black field earwig } \\
\text { (v) Surface Grasshopper } \\
\text { (vi) Short Horn Grasshopper } \\
\text { (vii) Long Horn Grasshopper }\end{array}$ & $\begin{array}{l}\text { Agrotis ipsilon } \\
\text { Teleogryllus spp. } \\
\text { Lepidogyyllus spp. } \\
\text { Nala lividipes } \\
\text { Chrotogonus trachyptrus } \\
\text { Attractomorpha crenulata } \\
\text { Neoconocephalus spp. }\end{array}$ & $\begin{array}{l}\text { Lepidoptera: Noctuidae } \\
\text { Orthoptera: Gryllidae } \\
\text { Orthoptera: Gryllidae } \\
\text { Dermaptera: Labiduridae } \\
\text { Dermaptera: Labiduridae } \\
\text { Dermaptera: Labiduridae } \\
\text { Dermaptera: Labiduridae }\end{array}$ \\
\hline 2 & $\begin{array}{l}\text { Stem Feeders } \\
\text { (i) Stem weevil } \\
\text { (ii) Treehoppers }\end{array}$ & $\begin{array}{l}\text { Cylindrocopturus adspersus } \\
\text { Vanduzea laeta }\end{array}$ & $\begin{array}{l}\text { Coleoptera: Curculionidae } \\
\text { Homoptera: Membracidae }\end{array}$ \\
\hline 3 & $\begin{array}{l}\text { Sucking pests } \\
\text { (i) Whitefly } \\
\text { (ii) Jassid/Leafhopper } \\
\text { (iii) Aphids } \\
\text { (iv) Thrips }\end{array}$ & $\begin{array}{l}\text { Bemisia tabaci } \\
\text { Amrasca devastans } \\
\text { Aphis gossypii } \\
\text { Thrips tabaci }\end{array}$ & $\begin{array}{l}\text { Homoptera : Aleyrodidae } \\
\text { Homoptera : Cicadellidae } \\
\text { Homoptera : Aphididae } \\
\text { Hemiptera: Thripidae }\end{array}$ \\
\hline 4 & $\begin{array}{l}\text { Defoliators } \\
\text { (i) Leaf beetle } \\
\text { (ii) Tobacco caterpillar } \\
\text { (iii) Cabbage semilooper } \\
\text { (iv) Hairy Caterpillar }\end{array}$ & $\begin{array}{l}\text { Zygorgama exclamationis } \\
\text { Spodoptera litura } \\
\text { Thysanoplusia orichalcea } \\
\text { Spilosoma oblique }\end{array}$ & $\begin{array}{l}\text { Coleoptera: Chrysomelidae } \\
\text { Lepidoptera: Noctuidae } \\
\text { Lepidoptera: Noctuidae } \\
\text { Lepidoptera: Arctiidae }\end{array}$ \\
\hline 5 & $\begin{array}{l}\text { Head and Seed Feeders } \\
\text { (i) Capitulum borer } \\
\text { (ii) Brown stink bug } \\
\text { (iii) Seed weevil }\end{array}$ & $\begin{array}{l}\text { Helicoverpa armigera } \\
\text { Euschistus servus } \\
\text { Smicronyx spp. }\end{array}$ & $\begin{array}{l}\text { Lepidoptera: Noctuidae } \\
\text { Hemiptera: Pentatomidae } \\
\text { Coleoptera: Curculionidae }\end{array}$ \\
\hline
\end{tabular}

Seedling and root feeding pests

During the survey, it was found that seedling pests generally cut sunflower seedlings soon after emergence and pest attack was started 
atearly stage of the plant development during both spring and autumn seasons. In case of spring-sown crops 2012-2013, infestation of these pests were observed during third and fourth weeks of March until second week of April. Similarly, the feeding damage of seedling and root feeding pests was recorded during end of July in autumn season.

Among seedling and root feeding pests cutworms, black field crickets, grasshoppers and black field earwigs were recorded in Peshawar, Mardan and Swabi districts. It was observed that cutworms cut off on new emerged seedlings and young plants below or above the soil surface usually at night, while rest at daytime near the freshly damaged plants inside the soil. Similar findings on seedling feeding pests of sunflower have previously report by [21, 22]. Because of seedling pests attack on crop, sometimes the plant stand of sunflower plant is reduced up to 30 percent [23].

[24] reported that cutworm, Agrotis ipsilonis a devastating insect pest of sunflower. According to $[25,26]$ cutworm generally cut off the sunflower plants at the base and cause severe damage to the crop. [27, 28] described that cutworm, Agrotis ipsilon is a key insect pest of sunflower at their seedling stage. The cutworm caterpillars cut the immature seedlings just above the ground level during night times.

Field crickets recorded during the field survey had flattened bodies with long antennae, which can be confused with grasshoppers because they have similar body structure with jumping hind legs. Field crickets are normally minor and irregular insect pests of sunflowers. They tend to be nocturnal and feed on the leaves and stems of seedlings above ground level. Findings of the present study strongly corroborate earlier reports made by [29] who reported that a complex of soil-dwelling insect pests and different seedling insects heavily infested sunflower crop in Queensland, Australia. Two species of field crickets (Lepidogryllus spp. and Teleogryllus oceanicus) caused heavy damage to sunflower seedling plants. Different species of grasshopper i.e. long horned grasshopper, short horned grasshopper and surface grasshopper were recorded during the course of investigation. Attack of grasshopper species was noticed in various stages of crop development. Grasshopper is polyphagous pest of different field crops including sunflower. All species of grasshoppers cause considerable damage to sunflower seedlings. Previous reports made by [30] stated that surface grasshopper (Chrotogonus spp.) is a serious pest of sunflower and cause significant losses to the crop. [31] also reported that Orthoptera is the largest order of insects consisting of short horned and long horned grasshoppers with widespread distribution throughout the India.

Black field earwigs were recorded as occasional and minor pests of sunflower. They were found feeding on freshly sown seeds, germinating seed and roots of the crops below ground level, which resulted in week establishment and poor population of the plants. Earwigs also chew the stems of newly emerged seedlings above ground. Our results are strongly supported by [29] who reported the attack of black field earwigs, Nala lividipes (Dermaptera: Labiduridae) on sunflower seedlings in Queensland, Australia.

\section{Stem feeders}

The sunflower crop damage during different phenological stages was observed by several stem feeding insects, which mainly included larvae of stem borer, the sunflower stem weevil and tree hoppers.It was noticed that larvae of stem borer make tunnels in the stems of sunflower. Lodging of the plants in the field is a good indicator of larvae of stem borer; however, lodging also is influenced by other factors like wind etc. Because of 
stem bored larval infestation, the foliage becomes yellow in appearance and finally wilts. Damage of stem weevil was recorded in later stage of the crop development during last week of May to fourth week of June. [32] reported that the infested sunflower plants get dried up, turn black and have a sickly appearance. Damage is greater in plants grown in deep black soil $(94.72 \%)$ than sandy soils (70.64\%). [33] reported that the sunflower stem weevil, Cylindrocopturus adspersus (LeConte) is a major pest of sunflower in North and South Dakota, Minnesota, and Texas in the United States.

The treehoppers (Membracidae: Homoptera) are small sucking insect pests reported on sunflower for the first time in Pakistan. During spring season, the attack of treehoppers generally started from third week of May until third week of June, whereas their incidence was observed in the second week of September until harvesting of the crop. Infestation of treehoppers was observed at the base of the leaf stem and found on junction of leaf and stem of the plant, feeding on both portions. The distinguishing character of treehoppers is their long pronotum, which most often resembles horns. Upon feeding, they secrete sweet sticky material honeydew that most often attracts ants. The present findings are similar to that of the earlier investigations made by [34] that a treehopper, Vanduzea laeta is a common insect pest of cultivated sunflower as well as on several species of Helianthus in Southern latitudes. The treehoppers colonize stems of plant terminals and leaf petioles of sunflower, and usually tended by many ants because of the secretion of sweet sticky material.

\section{Sucking pests}

Sucking pests feed on stem and sap of leaves, which mainly include whitefly $(B$. tabaci), leafhopper (Am. devastans), aphids (Ap. gossypii) and green stink bug (Nezera viridula). Infestation of sucking insect pests starts from early stage of the crop and succeed throughout entire plant development period. During spring season, 2012-2013, the infestation of whitefly was initially noticed through $4^{\text {th }}$ week of April and continued until the crop is harvested. While in case of autumn sown-crop, their incidence was observed during second week of August and remained present throughout the season. Heavy infestation of the pest was recorded in the last week of August until the first week of September. Similarly, during spring season, leafhopper infestation was started in the third week of April and continued until the end of May, whereas heavy infestation was observed in the $2^{\text {nd }}$ week of May. During autumn 2012-2013, the pest appeared in small numbers during mid of August and showed their presence until the last week of September. Sucking pests damage the crop significantly and ultimately reduce the yield up to a great extent [30]. These are polyphagous insect pest with piercing sucking type of mouthparts and damage the crop in both the adult and immature stages. According to [35] they also play a fundamental role in the transmission of viral diseases. Similarly, [36] also reported that stunted growth of plants, cupped and crinkled leaves and burnt appearance of leaf margins are symptoms of damage by various sucking pests of sunflower. While sucking the cell sap from plant tissues, they infuse very toxic saliva into the tissues resulting into a condition known as hopper burn or toxemia. Necrotic spots appear on the leaves in case of heavy infestation and the leaves turn inward that lead the plant to yellowing, curling and wilting. [37] reported that A. devastans nymphs and adults damage plants by sucking cell sap from their leaves, which consequently result in leaf curling, drying, burning, and growth retardation. It was observed that low relative humidity and high 
daily maximum temperature have significant positive correlation with their population density.

[38] reported that aphid feed on cell sap of the plants is an emerging serious insect pest in India. [39] also reported that aphid, Ap. gossypii feed on more than 70 different important host plants in Iran. The present results are in agreement with that of $[40,41]$ who reported that leafhoppers suck plant juices that results in leaf curling, burning, drying, and stunted growth of plants. [42] also observed that leafhopper, among all the sucking insect pests is the most important pest of sunflower. According to [43] the whitefly damages the crop extensively and reduces the crop yield up to a great extent. [44] also reported that whitefly attacks cotton, vegetables and sunflower. Whitefly not only damages the crops seriously, but also serves as carrier for viral infections and plays a vital role in the transmission of diseases [45]. [46] also reported heavy losses by Hemipterans.

Green stinkbugs are polyphagous pests of many crops, feeding usually on seeds, kernel and immature fruits of the plants. The body structure of green stinkbug is flat and shieldlike, about half an inch in size and dark green color. The damage mainly results in dropping and malformation of seeds and fruits. They suck the cell sap and fluids from the tissues, buds, flowers and tender leaves by piercing their mouthparts. On each feeding site, a hard-bitten spot appears. The pest is active throughout the year, [47] stated that green stink bug is mainly attracted to fruit trees and pods of host plants, including corn, soybean, cotton, sunflower and sorghum. They feed on their fruiting structures, causing cost-effective losses to the crops. [48] demonstrated that total losses because of stink bugs during the financial year 2004 were projected at $\$ 9.7$ million for the cotton industry across the United States.

\section{Defoliators}

Sunflower leaf beetle was initially observed in the last week of May and was showed their presence until maturity of the crop. Similarly, during spring season 2012-2013, heavy infestation of loopers and cabbage semilooper was observed in the second week of April, which was continued until the second week of May. The attack of cabbage semilooper was again noticed in the second week of August and their incidence remained present until harvesting of the crop. The incidence of hairy caterpillar was observed in the last week of September, which continued until the crop harvesting, however their infestation was not recorded during spring season.

Among foliage feeders or defoliators of sunflower, sunflower beetle or leaf beetle, tobacco caterpillars, cabbage or green semilooper and Loopers are the most serious and destructive insect pests. According to [49] the loss in seed yield due to defoliators in a rain fed Kharif crop was up to $268 \mathrm{~kg}$ $\mathrm{ha}^{-1}$. If the defoliators attack is before flower initiation it would affect food partitioning between stem, leaves and roots and if it were later, it would affect growth of both vegetative parts and inflorescence.

Sunflower beetle is a small leaf-feeding pest that looks like Colorado potato beetle in general appearance. Because of their harsh feeding habits on leaves, defoliation occurs which may reduce sunflower yield and later on show a negative impact on seed setting. $[50,51]$ stated that both adult and larvae of sunflower beetle damage the sunflower crop. Adult sunflower beetle feed insensitively on sunflower foliage near the leaf margins mostly during day times, while their larvae are normally nocturnal and feed overall leaf surfaces. [52] reported that sunflower beetle is a key pest of sunflower crop in North America. Larvae of Sunflower beetle have aggregate distribution in the sunflower fields that severely damage the crop. 
Tobacco caterpillars being a polyphagous pest of sunflower was observed in all sunflower growing areas. The pest was found feeding gregariously on foliage mostly during night hours, and observed burying in soil and nearby debris during daytime. Early instars larvae voraciously feed on green content of the leaves that give a mesh like look to smashed leaves, older larvae cause total defoliation of the plants. Larvae of cabbage or green semilooper are dark green in color having a thin white marginal line and two white lines on its back. They are mostly swollen at posterior end and tapers interiorly. Cabbage semiloopers are regular and serious pest of sunflower crop, mostly feed on young leaves. Loopers are rare pests of sunflower. They are similar to Helicoverpa but can be distinguished by making a full loop while moving.

[53] found that tobacco caterpillar ( $S$. liturae), is a potential defoliator among all the sunflower insect pests. Observation made by [54] further confirms our findings, that cabbage semilooper, Plusia orichalcea is one of the major devastating pest among all different insect pests associated with sunflower in Kenya. [55] also, endorse our results, reported cabbage semilooper (Thsanoplusia orichalcea) as the most important and key pest of sunflower.

Hairy caterpillar is a polyphagous pest, feed on a number of plants of economic importance and can be seen throughout the year. Immature larvae feed gregariously on lower surface of sunflower leaves. In the larval stage, they have numerous hairs on their body, that is why know as hairy caterpillar. Their feeding habit is so voracious that they eat the entire chlorophyll substance of the leaves while only the veins are left.

[56] reported that heavy infestation of hairy caterpillar, S. obliqua on sunflower crop was recorded at Latur districts in India during
1985-86. Because of Spilosoma attack, the sunflower plants were severely damaged during kharif season at Latur in 1993. [57] strongly verify our findings that hairy caterpillar (D. oblique) is a major pest of sunflower, which seriously damaged sunflower plants during second week of October.

\section{Head and seed feeders}

The presence of $H$. armigera was noticed on newly emerged leaves in the second week of April and was continued until formation of buds and seeds on capitulum of sunflower. The incidence of seed weevil was noticed in the first week of June and their presence was observed until maturity of the crop. Infestation of thrips was recorded at the early stage of the crop but heavy incidence was recorded on capitulum of sunflower during June and was remained active until harvesting of the crop.

Capitulum borer or head borer is a polyphagous and potential insect pest of sunflower. The infestation of sunflower crop by Helicoverpa was found at young stage of the crop and it was noticed that their feeding continued up to budding and seed formation of the crop. Newly hatched larvae feed on leaves, buds and flowers while, grown up larvae bore inside the disc and feed on the developing seed. [58] reported the infestation of $H$. armigera on sunflower crop. Similarly, findings of [59, 60] also confirm our results who observed the infestation of $H$. armigera on sunflower.

Heavy incidence of thrips on seedlings and floral heads of sunflower was recorded during the present field survey in all three districts. Both adults and nymphs feed on the leaves and capitulum by rasping the surface tissues and sucking the exuded juices. Their feeding collapse plant cells and may result in deformed flowers, leaves and shoots. It was found that severe infestation of thrips on young plants caused deformation and browning of the leaves. A 
number of thrip species are potential vectors of pathogens like tobacco streak virus (TSV) which is also previously reported by [61] thrip does not harm the sunflower crop significantly, but they serve as a vector of many viral infections and cause heavy losses indirectly. Sunflower necrosis is principle example of such association caused by tobacco streak virus. [62] further authenticated our investigations who stated that thrip (T. tabaci) is a sucking pest of sunflower observed on leaves but mostly found on capitulum portion of the crop.

The brown stinkbug, Euschistus servus was also found on capitulum of sunflower. It feeds on the vegetative parts, flowers, stems and foliage of sunflower. The attacked leaves contain lesions and ultimately become brown. The extent of damage mainly depends on the developmental stage of the crop.

The present research findings greatly comply with that of previous reports made by [63-65] who reported that stink bugs, particularly those of pentatomidae family are considered one of the most important insect pests of soybean crop thorough out the world. [66] also reported that brown colored stink bug, Euschistisheros is presently the most abundant specie of stink bugs particularly in the central states of Brazil.

\section{Pollinators associated with sunflower}

Table 2 shows pollinator species associated with sunflower, which mainly include different Apis and non-Apis species. Lepidopterous comprised of milkweed butterfly, cabbage butterfly, yellow butterfly, diamondback moth and swallowtail butterflies. Among the dipterans, syrphid fly was recorded as pollinating agent of sunflower. During the course of survey, it was revealed that all these insect visitors were equally distributed in Peshawar, Mardan and Swabi districts of Khyber Pakhtunkhwa and no specific pollinating species was recorded to be confined to any specific district.

Table 2. List of different pollinator species recorded on sunflower in Peshawar, Mardan and Swabi districts of Khyber Pakhtunkhwa during 2012-2013

\begin{tabular}{|l|l|l|l|}
\hline S. No. & Common Name & Scientific Name & Order and Family \\
\hline 1 & European Honeybee & Apismellifera & Hymenoptera:Apidae \\
\hline 2 & Small Honeybee & Apisflorea & Hymenoptera:Apidae \\
\hline 3 & Local Honeybee & Apiscerana & Hymenoptera:Apidae \\
\hline 4 & The Giant Honeybee & Apisdorsata & Hymenoptera:Apidae \\
\hline 5 & Carpenter bee & Xylocopairridipinis & Hymenoptera: Apidae \\
\hline 6 & Green Metalic bee/ (Halictus bee) & Halictus spp. & Hymenoptera: Apidae \\
\hline 7 & Syrphid fly & Eristalinnus spp. & Diptera: Syrphidae \\
\hline 8 & $\begin{array}{l}\text { Other pollinator species } \\
\text { (i) Milkweed butterfly } \\
\text { (ii) Cabbage butterfly } \\
\text { (iii) Swallowtail butterfly } \\
\text { (iv) Diamondback moth } \\
\text { (v) Yellow butterfly }\end{array}$ & $\begin{array}{l}\text { Danauschrysippus } \\
\text { Pierisbrassicae } \\
\text { Papiliopolystes } \\
\text { Plutellaxylostella } \\
\text { Catopsillacorrcle }\end{array}$ & $\begin{array}{l}\text { Lepidoptera:Danaidae } \\
\text { Lepidoptera:Pieridae } \\
\text { Lepidoptera:Papilionidae } \\
\text { Lepidoptera:Plutellidae } \\
\text { Lepidoptera:Pieridae }\end{array}$ \\
\hline
\end{tabular}

Among all the observed pollinator species on sunflower, honeybees recorded the most active and principal group of insect visitors of sunflower and constituted major species involved in sunflower pollination. Honeybee is a highly social insect classified as $A$. 
cerana, A. mellifera, A. florea, and A. dorsata. They are famous for its honey production and can be easily domesticated. They are very important pollinators, adoptable to a wide range of habitats and play a vital role in providing pollination for many plants of economic importance. Pollens of sunflower are heavy and sticky in nature, and cannot be carried by wind [66]. Therefore, honeybees are the primary source of pollination for better yield and improved seed setting. Capitulum or floral heads of sunflowers are very conspicuous that attract a large number of pollinators fauna, but among all pollinators the most fundamental, efficient and commercially important pollinator are the honeybee species.

Besides honeybees, other pollinator species like Xylocopa spp., Halictus spp., wasps, syrphid fly etc. were also recorded on the crop during the course of survey. Visitation by other pollinator species, like Dipterans (flies) and Lepidopteron (milkweed butterfly, cabbage butterfly, yellow butterfly, diamondback moth and swallowtail butterflies), their incidence were also recorded.

[67] reported that in Viamão (Brazil), 96\% of the total sunflower insect visitors have been recorded as honeybee, A. mellifera L. Similarly, [68] stated that the European honeybee, A. mellifera L. is a typical and a standard for pollination of many crops. [69, 70] stated that the bumblebees nest or colonies are not as large and well managed as those of honeybees. The bumblebees are strongly built and tough-bodied pollinators, and are capable to work even under cooler and moist environmental conditions than do honeybees. [71] also elaborated that bumblebees are excellent pollinators of sunflower. Due to pollination services provided by these two potential pollinators, total number of seed, seed weight, and relative seed set has significantly increased.
Unfortunately bumblebees were not found visiting the sunflower.

$[72,73]$ stated that Non-Apis bees have also been reported to pollinate sunflower and significantly improve the crop yield by enhancing the effectiveness of A. mellifera. [74] also reported that carpenter bees help in pollination of many economically important crops, including blackberry, canola, corn, pepper, pole bean, and sunflower. The findings of present research study are in agreement with that of [75] who reported that the Syrphidae are among the most essential pollinating flies in Ontario. The larval stage of syrphid fly have a very unusual ecology, since some species can grant supplementary advantage to crops as the larvae prey on slow-moving and softbodied insects like aphids. Similarly according to the previous reports of [76-84] syrphid flies are widespread pollinators and can be found wherever flowers are existing. [85] reported that halictids (Hymenopetra) also known as sweat bees are good pollinators of sunflower.

\section{Natural enemies associated with sunflower}

Table 3 indicates list of different predators and parasites associated with sunflower, whichmainly consisted of ladybird beetle, green lacewing, praying mantis, syrphid flies, tachinid flies and certain species of spiders. All these beneficial faunawere equally occured in Peshawar, Mardan and swabi districts of Khyber Pakhtunkhwa and no predator species was confined to a specific area.

Natural enemies are classified broadly as parasites, predators or parasitoids. Both the adult as well as immature stages of a beneficial insect play an important role in consuming many insect pests as their prey during their development. Natural enemies associated with sunflower include ladybird beetle, green lacewing, praying mantis and syrphid flies and tachinid flies. All these 
insect species are important predators, which feed on majority of insect prey.

Among all the different species of natural enemies found on sunflower, lady bird beetles and spiders were the most abundant species, which constituted major group of all beneficial insects of the crop, followed by syrphid fly, praying mantids and green lace wing. Most of the ladybird beetles are beneficial natural enemies as both adults and larvae and feed on aphids, mites, soft-bodied insects, and eggs of many small insects.

Table 3. List of different beneficial fauna (Biocontrol agents) recorded on sunflower in Peshawar, Mardan and Swabi districts of Khyber Pakhtunkhwa during 2012-2013

\begin{tabular}{|c|c|c|c|}
\hline S. No & Common Names & Scientific Names & Order and Family \\
\hline 1 & Ladybird Beetle & Coccinellaspp. & Coccinellidae:Coleoptera \\
\hline 2 & Green Lacewing & Chrysoperlacarnea & Neuroptera:Chrysopidae \\
\hline 3 & Tachinid Flies & Trichopodapennipes & Diptera:Tachinidae \\
\hline 4 & Preying Mantid & Mantis religiosa & Insecta:Mantodea \\
\hline 5 & Syrphid fly & Toxomerus geminates & Diptera:Syrphidae \\
\hline & & (i) Thomisusprojectus & Araneae:Thomisidae \\
& Spider species & (ii) Lycosakempi & Araneae:Lycosoidae \\
6 & & (iii) Hippasaagelenoides & Araneae:Lycosidae \\
& & (iv) Lycosatesta & Araneae:Lycosidae \\
& & (v) Lycosa Mackenzie & Araneae:Lycosidae \\
\hline
\end{tabular}

Majority of spiders found on sunflower were useful because they feed on small insects and other arthropods. Spiders are generally less noticeable arthropods found on sunflower. Similarly, green lacewing feed on a large number of small insect pests including aphids, whiteflies, thrips, psyllids and leafhoppers etc. and larvae are also known as aphid loins. Tachinid flies are similar in appearance to common houseflies, but differ clearly in their habits than common flies. Color of tachinid flies varies from brown to gray and its body is covered with small hair like spines. Praying mantids are commonly green or brown colored insect, large and much prominent in appearance because of their well-modified frontal legs use for holding the preys.

[86] described that majority of the predaceous coccinellids are entirely efficient predators of aphids, mealybugs, scale insects, whiteflies, thrips, leafhoppers, mites and other small and soft-bodied insect pest species. [87, 88] also stated that ladybird beetles are the most important biological control agents of aphids, mealybugs, scales, mites and other soft-bodied insect pests. Findings of [89] are in agreement with that of our present results who reported that $C$. carnea effectively controlled the Population density of $B$. tabaci in different cotton genotypes in Pakistan. Likewise, according to [90-92] green lacewing, $C$. carneais a good biological control agent which feed on a variety of different pest species like aphids, thrips, whiteflies and mites etc. [93] reported that larval stage of tachinid flies are potential parasitoids and feed on different arthropods species. Tachinid fly species Trichopoda pennipesis the most victorious natural enemy of geen stink bug, Nezara viridula nymphs and adults [94-98].

[99] reported that that praying mantids are efficient predators of many insect pests. Findings of [100] strongly verified our results on lady bird beetles and stated that larval stage of lady bird require aphid consumption for their development. [93] further endorsed our findings about syrphid flies that the syrphid flies or hover flies have been recorded as one of the competent bio control agents of aphids. [99, 100] 
investigated that the spider are efficient predators in reducing small and soft-bodied insects. Similarly, [83] also reported that spiders associated with maize crop voraciously feed on leafhoppers, thrips, and aphids.

\section{Conclusion}

Based on survey in three districts of Khyber Pakhtunkhwa, different pests associated with sunflower were mainly divided into five groups i.e. seedlings pests, stem feeders, sucking pests, defoliators/foliage feeders and capitulum feeders. In addition to insect pests, many other beneficial insect species were also recorded on the crop. The collected fauna were also comprised of insect visitors such as Hymenoptera, Lepidoptera and Diptera however, Honeybees were recorded the leading group of pollinators on sunflower.

\section{Authors' contributions}

Conceived and designed the experiments: F Said, Performed the experiments: F Said, Analyzed the data: F Jalal, Contributed materials/ analysis/ tools: M Imtiaz, MA Khan \& S Hussain, Wrote the paper: F Said.

\section{Acknowledgements}

The author extend sincere gratitude to Prof. Dr. Mian Inayatullah, Chairman, Department of Entomology for the technical support throughout the experiment and Farm Manager, New Developmental Farm (NDF) for providing experimental plot. The financial assistance provided by the Higher Education Commission (HEC) Islamabad, Government of Pakistan is also highly acknowledged.

\section{References}

1. Pakistan Oil Seed and Products Annual Reports (2010). 233-235.

2. Khan SN, Ayub N, Ahmad I, Shehzad I \& Asad (2007). Effect of climatic conditions on life cycle of charcoal rot infected sunflower plant. Pak J Bot 39: 2657-2662.

3. Burney K, Ahmad I \& Aslam M (1990).
Charcoal rot and important diseases of sunflower and its control. Prog Farm 10(6): 34-36.

4. Agricultural Statistics of Pakistan (2013). Government of Pakistan Statistics Division Pakistan Bureau of Statistics. 145-153.

5. Carl DP (1990). Managing insect pests of Taxas Sunflower. Taxas Agricultural Extension.

6. Rogers CE (1988). Insects from native and cultivated sunflower (Helianthus annuus) in Southern latitudes of the United States. J Agric Entomol 5(4): 267-287.

7. Aslam M, Suleman N, Riaz A, Rehman, A \& Zia Q (2000). Insect pests found on Helianthus annuus L. (Compositae) in the Potohar Region of Pakistan. Pak J Biol Sci 3: 963-964.

8. Rafiullah, Farma ullah S, Subhan F \& Ahmad R (1998). Screening of sunflower genotypes against pests under field conditions. Sarhad J of Agric 14: 591595.

9. Anonymous (1997). Annual Progress Report. All India Research Project on Sunflower, Directorate of Oilseeds Research, Hyderabad, India, 146-163.

10. Furgala B, Noetzel DM \& Robinson RG (1979). Observations on the pollination of hybrid sunflowers. Proc. IVth Int. Symp. On Pollination. Md Agric Exp Sta Spec Misc Publ 1: 45-48.

11. Moreti, ACD, Silva C, Alves ML, Silva RM \& Otsuk IP (1993). Initial observations regarding the pollination of sunflower (Helianthus annuss L.) by Apis mellifera L. Pindamonhangaba, Sao Paulo. Boletim de Industra Animal 50: 31-34.

12. Jyoti J \& Brewer G (1999). Effect of honeybee (Hymenoptera: Apidae) pollination on sunflower hybrids. Proc 21st Sunflower Research Workshop. Nat Sunflower Assoc pp 103-107. 
13. Hodek I (1967). Bionomics and ecology of predacious Coccinellidea. Ann Rev Entomol 12: 79-104.

14. Kenervo V (1940). Beobachtungen und Verscuche zur Ermittlung der Nahrung einiger coccinelliden. Ann Entomol Fenn 6: 89-110.

15. Singh T, Singh VK \& Singh RN (1991). Influence of intercropping: III. Natural enemy complex in groundnut. Ind $J$ Entomol 53: 333-368.

16. Merril R (2008). Attracting beneficial insects to the garden with beneficial flowers. Renee's Garden. Graham Hill RD Flton 1-8.

17. Thalji R (1994). Occurance and distribution of Aphdophagous lady birds on agricultural crops and wild Plants in Vojvodine. Zastita Bilji pp 279-291.

18. Ramesh A, Sukhwinder K, Dhillon K, Arora AS, Kaur S, Dhaliwal GS. Arora $\mathrm{R}$, Randhawa NS \& Dhawan AK (1998). Manipulation of date of sowing for natural control of Insect pests in agro ecosystem. Ecol Agric and sust Dev 1-2: 449-456.

19. Lohar MK (Ed) (1994). Hand book of agricultural and veterinary applied entomolgy. Departmant of Entomology, Sind Agric Univ Tandojam, Pakistan pp 255.

20. Borrer DJ, DeLong DM \& Triplehorn CA (Eds) (1981). An Introduction to the study of insects. Fifth edition. Saunders College Publishing New York pp 827.

21. Rangarajan AV, Mahadevan NR \& Iyemperumal S (1975). Pest complex of sunflower (Helianthus annuus Linn.) in Tamil Nadu. Ind J Entomol 37: 188189.

22. Sandhu GS, Brar KS \& Bhalla JS (1973). Pests of sunflower and other insects associated with sunflower crop. Oilseeds $J$ 3: 19-26.

23. Basappa H \& Bhat NS (Eds) (1998). Pest management in sunflower seed production, In: Hybrid Sunflower Seed Production Technology Directorate of Oil seeds Research Hyderabad 62-66.

24. Aslam M (1994). Combating pests ravaging sunflower. Science and Technology. The Nation VI: 9.

25. Hashmi AA (1994). Insect Pests of Oilseed Crops. P147-191. In Edits. AA Hashmi. Insect Pest Management. Cereal and Cash Crops. Pak Agric Res Council Islamabad 1: 317.

26. Hatam M (1994). Oilseed Crops. In Edits N Shafi, E Bashir and R Bantel. Crop Production 329-389.

27. Rohilla HR, Singh VH, Gupta DS \& Singh K (1980). Pest complex other than diseases of sunflower in Haryana. Indian J Plant Protn 8: 177-182.

28. Khan AR, \& Aslam M (1981). Sunflower cultivation in Potohar Plateau and adjacent areas. Prog Far (PARC) 1: 28-32.

29. Simpson GB (1993). An improved soil insect rating for seedling sunflowers $(H$. annuus L.) Aus J Ex Agric 33(7): 931933.

30. Ashfaq M \& Aslam M (2001). Response of different insect pests to some sunflower genotypes and their correlation with yield component under field conditions. J Biol Sci 1(9): 835-839.

31. Joshi PC, Lockwood JA, Vashishth N \& Singh A (1999). J of Ortp Res 8: 17-23.

32. Veda OP \& Shaw SS (1994). Record of stem boring beetles on sunflower in Jhabua Hills of MP. Res 23(100): 18119.

33. Charlet LD (1987). Seasonal dynamics of the sunflower stem weevil, Cylindrocopturus adspersus (Leconte) (Coleoptera: Curculionidae), on cultivated sunflower in the Northern Great Plains. The Can Entomol 119(12): 1131-1137.

34. Rogers CE (1988). Insects from native and cultivated sunflower (Helianthus 
annuus) in Southern latitudes of the United States. J Agric Entomol 5(4): 267-287.

35. Rao CS (2002). First report of Tobacco Streak Virus infecting safflower (Carthamus tinctorius) in Maharashtra, India. Plant Diseases 87: 1396.

36. Saritha R, Dharma K, Reddy \& Basappa $H$ (2008). Screening of sunflower varieties for resistance against sucking pests. Indian J Plant Prtn 36(1): 1444147.

37. Srivastava KP (1993). A Text Book of Applied Entomology, Kalyani Publishers. Ludhiana, India.

38. Takalloozadeh HM (2010). Effects of host plants and various temperatures on population growth parameters of Aphis gossypii Glover (Homoptera: Aphididae). Middle East J Sci Res 6(1): 25-30.

39. Vennila S (2008). Pest management for cotton ecosystems or ecosystem management for cotton production? Curr Sci 94(11): 1351-1352.

40. Pradeepa S \& Regupathy R (2002). Generating base line data for insecticide resistance monitoring in cotton leafhopper, Amrasca devastans (Distant). Resistance Pest Management Newsletter 11 (2): 4-6.

41. Kumar RK \& and Bhatt NS (2012). Biology of leafhopper, Amrasca biguttula biguttula (Ishida) on sunflower. Karnataka J Agric Sci 25(4): 543-544.

42. Oliveira MRV, Henneberry TJ \& Anderson P (2001). History, current status and collaborative research project for Bemisia tabaci. Crop Protn 20: 709723.

43. Singh J, Sohi AS, Mann HS \& Kapur SP (1994). Studies on whitefly, Bemisia tabaci transmitted cotton leaf curl disease in Punjab. J Insect Sci 7: 194198.
44. Kataria R \& Kumar D (2012). Occurrence and Infestation Level of Sucking pests: Aphids on various host plants in Agricultural Fields of Vadodara, Gujarat (India). Intl J of Sci and Res 2: 7.

45. McPherson JE \& McPherson RM (2000). Stink bugs of economic importance. CRC, Boca Raton, FL.

46. Williams MR (2005). Cotton insect losses in 2004, pp 1105-1160. In JJ Adamczyk, Jr, and E. Burris [eds.], Proceedings, Beltwide Cotton Conferences, 4-7 January 2005, New Orleans, LA. National Cotton Council, Memphis, TN.

47. Basappa H (1997). Incidence of biocontrol agent Zygograma bicolorata Pallister at parthenium hysterophorus $\mathrm{L}$. pp 81-84. Mahadevappa, M and Patil, V.C. (Eds). In: First International conference at Parthenium Management, University of Agricultural Sci Dharwad Karnataka India 2: 182.

48. Charlet LD (1991). Overwintering survival and emergence pattern for the sunflower beetle (Coleoptera: Chrysomelidae) in the northern Great Plains. J of Eco Entomol 84: 132-135.

49. Charlet LD (1992). Seasonal abundance and parasitism of the sunflower beetle (Coleoptera: Chrysomelidae) on cultivated sunflower in the northern Great Plains. J of Eco Entomol 85: 766771.

50. Brewer GJ \& Charlet LD (2004). Sunflower beetle (Coleoptera: Chrysomelidae): pattern of larval distribution and parasitism in cultivated sunflower fields. J Kansas Entomol Soc 77: 21-25.

51. Basappa H (2008). Integrated Pest Management in Sunflower, in short course manual on Advances in Implementable Pest Management Technology, Directorate of Oilseeds 
Research, Hyderabad, India.

52. Khaemba BM \& Mutinga MJ (1981). Insect pests of sunflower in Kenya. Int $J$ Tropical Sci 3: 281-286.

53. Bakhetia DR, Sukwinder C, Kaur IS, Sandhu DS \& Kular JS (1997). Monitoring of insect pests and quantification of yield losses in sunflower. J Insect Sci 10(2): 140-142.

54. Geol and Kumar A (1993). Insect pests and predators associated to sunflower in winters of North India. Ind J Entomol 52: 39-45.

55. Kakakhel SA, Islam $N$ Amjad $M$ \& Malik MA (2000). Insect Pest Complex of Sunflower, Helianthus annuus L. Pak. J Biol Sci 3(4): 669-671.

56. Makhdoomi, A, Bhatti MN, Zia MA \& Shafique M (1984). Studied on insects associated with sunflower crop in Faisalabad. J Agric Res 22: 51-62.

57. Hassan AM, Mahmood T \& Ahmad MA (1984). Insect Pests of Sunflower at Faisalabad. PARC Proc. Nat. Sunflower Workshop. April 28-30, Barani. Agric. Res. and Div. Proj. NARC, Islamabad. pp. 39.

58. Sattar A, Ullah K, Ahad A \& Yousaf M (1984), Insect pests of sunflower in N.W.F.P., Pakistan. Pak J Agric Res 5(4): 239-240.

59. Hanumantharaya L, Goud KG \& Naik LK (2008). Management of insect pests of sunflower using green lacewing, Chrysoperla caenea and neem seed kernel extract. Karnataka J Agri Sci 21(1): 130-133.

60. Turnipsed SG \& Kogaan M (1976). Soybean entomology. Ann Rev of Entomol 21: 247-282.

61. Vicentini R \& Jimenez HA (1977). El vaneao de los frutos en soja. INTA Serie Tecnica 47.

62. Panizzi AR \& Slansky F (1985). Review of phytophagous pentatomids (Hemiptera: Pentatomidae) associated with soybean in the Americas. Fla Entomol 68: 184-214.

63. Degrandihoffmann G \& Watkins JC (2000). The foraging activity of honeybees Apis mellifera and non Apis bees on hybrid sunflower (Helianthus annuus) and its influence on crosspollination and seed set. J Apicl Res 39: 37-45.

64. Hoffmann M (1994). Observações sobre a polinização entomófila de Helianthus annuus L. em Viamão, Rio Grande do Sul. An. Soc. Entomol. Bras Londrina 23(3): 391-397.

65. Paarmann W (1977). Studies in the role of bumble bees (Bombus spp.) in fruit tree pollination. Zeitschrift für Angewandte Entomologie 84: 164-178.

66. Bosch J, Kemp WP \& Trostle GE (2006). Bee population returns and cherry yields in an orchard pollinated with Osmia lignaria (Hymenoptera: Megachilidae). J of Eco Entomol 99: 408-413.

67. Aslan MM \& Yavuksuz C (2010). Effect of honeybee (Apis mellifera L.) and bumblebee (Bombus terristris L.) pollinators on yield and yield factors in sunflower (Helianthus annuus L.) production areas. J Ani and Vet Adv 9(2): 332-335.

68. Degrandihoffmann $G$ \& Watkins JC (2000). The foraging activity of honeybees Apis mellifera and non Apis bees on hybrid sunflower (Helianthus annuus) and its influence on crosspollination and seed set. J Apicl Res 39: 37-45.

69. Greenleaf SS, \& Kremen C (2006). Wild bees enhance honeybees' pollination of hybrid sunflower. Proceeding of the National Academy of Sci USA 103: 13890-13895.

70. Delaplane KS (1994). Honey bees and other pollinators. American Bee J 2122. 
71. Woodcock TS (2012). Pollination in the Agricultural Landscape: Best Management Practices for Crop Pollination. Canadian Pollination Initiative (NSERC-CANPOLIN) University of Guelph.

72. Modarres AM (1997). Syrphidae; 253254. In: List of agricultural pests and their natural enemies in Iran. Ferdowsi Univ Press 429.

73. Khiaban NG, Hayat R, Safaralizadeh M, \& Parchami M (1998). A faunistic survey of Syrphidae in Uromieh region. Proceeding of the $13^{\text {th }}$ Iranian Plant Protection Congress 231.

74. Dousti AF (1999). Fauna and Diversity of Syrphid flies in Ahwaz region. M.S. Thesis, Shahid-Chamran University. pp. 129.

75. Gharali B, Alichi M \& Radjabi GR (2002). The new records of syrphid flies (Diptera: Syrphidae). Proceedings of 14th Iranian Plant Protection Congress pp 348.

76. Alichi M, Asadi GH \& Gharali B (2002). Aphidophagus syrphids of Fars province. Proceedings of 14th Iranian Plant Protection Congress, pp. 181.

77. Goldasteh SH, Asadi BH, Shojaee M \& Baniameri VA (2002). Afaunistic survey of Syrphidae (Diptera) in Gorgan region. Proceeding of the 15th Iranian Plant Protection Congress, pp 168.

78. Sadeghi H, Kayvanfar N \& Mojtahedzadeh K (2002). Hover flies (Dip.: Syrphidae) fauna of Mashhad region. Proceeding of the 15th Iranian Plant Protection Congress pp 169.

79. Golmohammadi $\mathrm{G}$ \& and Khiaban $\mathrm{N}$ (2004). Hoverflies (Diptera: Syrphidae) fauna of wheat fields in Sistan region. Proceedings of 16th Iranian Plant Protection Congress pp 132.

80. Gilasian E (2005). New record of one genus and six species of Syrphidae
(Diptera) from Iran. J Entomol Soc Iran 25(1): 75-76.

81. Michener CD (2007). The Bees of the World, 2nd Edition. The Johns Hopkins University Press Baltimore MD 6-11, 23-29, 57-58, 319-412.

82. Omkar \& Pervez A (2000). Biodiversity in predaceous coccinellids (Coleoptera: Coccinellidae) in India. A review $J$ Aphidol 14: 41-66.

83. Bozsik A (2006). Susceptibility of adult Coccinella septempunctata (Coleoptera: Coccinellidae) to insecticides with different modes of action. Pest Manag Sci 62: 651-654.

84. Jalali MA, Tirry L \& and Clerq PD (2009). Food consumption and immature growth of Adalia bipunctata (Coleoptera: Coccinellidae) on a natural prey and a factitious food. Europ $J$ Entomol 106: 193-198.

85. Khuram Z, Faisal H, Rashid \& Khan R (2008). Effectiveness of Chrysoperla carnea (Neuropetra: Chrysopidae) on the population of Bemisia tabaci (Hemiptera: Aleyrodidae) in different cotton genotypes. J Agric Social Sci 112-116.

86. Canard M \& Principi MM (1984). Life histories and behavior. In Biology of Chrysopidae (M. Canard, Y. Semeria and T.R. New Eds.). Dr W Junk Publishers, The Hague 57-149.

87. Liu TX \& Chen TY (2001). Effects of three aphid species (Homoptera: Aphididae) on development, survival and predation of Chrysoperla carnea (Neuroptera: Chrysopidae). Appl Entomol Zool 36: 361-366.

88. Yadav R \& Pathak PH (2010). Effect of temperature on the consumption capacity of Chrysoperla carnea (Stephens) (Neuroptera: Chrysopidae) reared on four aphid species. The Bioscan 5: 271-274.

89. O'Hara JE (2008). Tachinid flies 
(Diptera: Tachinidae). 3675-3686. In, Encyclopedia of Entomology. Second Edition. JL. Capinera (Editor). Springer. Dordrecht, The Netherlands 4: 4346.

90. Todd JW \& Lewis WJ (1976). Incidence and oviposition patterns of Trichopoda pennies (F.) a parasite of the southern green stink bug, Nezara virudula (L.). J Ga Entomol Soc 11. 5054.

91. Buschman LL \& Whitcomb WH (1980). Parasites of Nezara viridula (Hemiptera: Pentatomidae) and other Hemiptera in Florida. Fla Entomol 63: 154-162.

92. Menezes EB, Herzog DC \& Almada PJ (1985). A study of parasitism of the southern green stink bug, Nezara viridula (L.) (Hemiptera: Pentatomidae), by Trichopoda pennipes (F.) (Diptera: Tachinidae). Ann Soc Entomol Bras 14: 29-35.

93. Jones WA (1988). World view of the parasitoids of the southern green stink bug, Nezara viridula (L.) (Heteroptera: Pentatomidae). Ann Entomol Soc Am 81: 262-273.

94. Menezes EB, Herzog DC \& Almada PJ (1985). A study of parasitism of the southern green stink bug, Nezara viridula (L.) (Hemiptera: Pentatomidae), by Trichopoda pennipes (F.) (Diptera: Tachinidae). Ann Soc Entomol Bras 14: 29-35.

95. Svenson GJ \& Whiting MF (2004). Phylogeny of Mantodea based on molecular data: evolution of a charismatic predator. Systematic Entomol 29: 359-370.

96. Schneider E (1969). Bionomics and physiology of aphidophagous syrphidae. Ann Rev of Entomol 14: 103-123.

97. Kotwal DR, Bhalla DP \& Verma AK (1984). Natural enemies of cabbage aphid, Brevicoryne brassicae (Linn.) in the mid-hill regions of Himachal Pradesh. Ind J Agrl Sci 54: 1011 - 1012.

98. Riechert SE (1999). The hows and whys of successful pest suppression by spiders: insights from case studies. $J$ Arachnol 27: 387.396.

99. Symondson WOC, Sunderland KD \& Greenstone MH (2002). Can generalist predators be effective biocontrol agents? Annu Rev Entomol 47: 561.594.

100. Lang A, Filser J \& Henschel JR (1999). Predation by ground beetles and wolf spiders on herbivorous insects in a maize crop. Agric Ecosyst Environ 72: 189-199. 